\title{
Dentinogenic Ghost Cell Tumor in a Sumatran Rhinoceros
}

\author{
Annas Salleh 1,*, Zainal Z. Zainuddin ${ }^{2} \mathbb{D}$, Reza M. M. Tarmizi ${ }^{2}$, Chee K. Yap ${ }^{2}$, Chian-Ren Jeng ${ }^{3}$ \\ and Mohd Zamri-Saad ${ }^{1}$ (D)
}

1 Department of Veterinary Laboratory Diagnosis, Faculty of Veterinary Medicine, Universiti Putra Malaysia, Serdang 43400, Selangor, Malaysia; mzamri@upm.edu.my

2 Borneo Rhino Alliance, c/o Faculty of Sciences and Natural Resources, Universiti Malaysia Sabah, Kota Kinabalu 88400, Sabah, Malaysia; zainalz.bora@gmail.com (Z.Z.Z.); reza2727@gmail.com (R.M.M.T.); kcyap@upm.edu.my (C.K.Y.)

3 Graduate Institute of Molecular and Comparative Pathobiology, School of Veterinary Medicine, National Taiwan University, Taipei 106216, Taiwan; crjeng@ntu.edu.tw

* Correspondence: annas@up.edu.my

check for updates

Citation: Salleh, A.; Zainuddin, Z.Z.; Tarmizi, R.M.M.; Yap, C.K.; Jeng, C.-R.; Zamri-Saad, M. Dentinogenic Ghost Cell Tumor in a Sumatran Rhinoceros. Animals 2021, 11, 1173. https://doi.org/10.3390/ ani11041173

Academic Editors:

Alejandro Suárez-Bonnet and Gustavo A. Ramírez Rivero

Received: 29 January 2021

Accepted: 16 April 2021

Published: 20 April 2021

Publisher's Note: MDPI stays neutral with regard to jurisdictional claims in published maps and institutional affiliations.
Simple Summary: A dentinogenic ghost cell tumor is an odontogenic ghost cell lesion of the maxilla and mandible. It is a rare tumor that has been described in humans. This work describes the clinical and pathological findings of an advanced stage of a dentinogenic ghost cell tumor, a type that has not previously been described in veterinary medicine. The advanced stage of this tumor led to the observation of aberrant keratinization, characterized by ghost cells and numerous islands of dentinoid formation. Diagnosis was made with the aid of routine histology, special histochemistry, immunohistochemistry, and classification and features from human oncology as a reference.

\begin{abstract}
An adult female Sumatran rhinoceros was observed with a swelling in the left infraorbital region in March 2017. The swelling rapidly grew into a mass. A radiograph revealed a cystic radiolucent area in the left maxilla. In June 2017, the rhinoceros was euthanized. At necropsy, the infraorbital mass measured $21 \mathrm{~cm} \times 30 \mathrm{~cm}$. Samples of the infraorbital mass, left parotid gland, and left masseter muscle were collected for histopathology (Hematoxylin \& Eosin, Von Kossa, Masson's trichrome, cytokeratin AE1/AE3, EMA, p53, and S-100). Numerous neoplastic epithelial cells showing pleomorphism and infiltration were observed. Islands of dentinoid material containing ghost cells and keratin pearls were observed with the aid of the two special histochemistry stains. Mitotic figures were rarely observed. All the neoplastic odontogenic cells and keratin pearls showed an intense positive stain for cytokeratin AE1/AE3, while some keratin pearls showed mild positive stains for S-100. All samples were negative for p53 and S-100 immunodetection. The mass was diagnosed as a dentinogenic ghost cell tumor.
\end{abstract}

Keywords: dentinogenic ghost cell tumor; odontogenic ghost cell lesion; Sumatran rhinoceros; Dicerorhinus sumatrensis; immunohistochemistry; special stain

\section{Introduction}

In humans, a few types of tumors are identified as odontogenic ghost cell lesions (OGCL) of the maxilla and mandible. This includes calcifying odontogenic cysts (COC), dentinogenic ghost cell tumors (DGCT), and ghost cell odontogenic carcinoma (GCOC) [1] DGCT is a benign but locally infiltrative neoplasm of odontogenic epithelium. It is a rare tumor in humans with very limited reports. A ghost cell is an enlarged epithelial cell having an eosinophilic cytoplasm with a faint nucleus outline or no nucleus [2]. It is associated with a marked aberrant keratinization. DGCT has been described as a rare form of ghost cell lesion, accounting for $3-5 \%$ of all cases involving ghost cell lesions $[3,4]$.

For OGCL in humans, the prognosis and recurrence rate may differ according to the type of tumor. For COC, prognosis is considered excellent and the recurrence rate is low. When recurrence of COC occurs, it typically involves elderly persons [5]. Recurrence in 
young persons is rarely reported [6]. For DGCT, reports on recurrence rates range between $33 \%$ and $73 \%$ [7]. Surgical removal of DGCT involving an extensive procedure usually results in a low recurrence rate, while simple enucleation of the tumor usually results in a higher recurrence rate. Recurrence may occur within 5 to 10 years [8]. GCOC has a 73\% five-year survival rate, and recurrence is reported to be common [9].

To our knowledge, DGCT has never been documented in animals. This article reports the first case of DGCT in an animal.

\section{Description of the Case}

A female Sumatran rhinoceros (Dicerorrhinus sumatrensis) weighing $508 \mathrm{~kg}$ and estimated to be between 25 and 30 years old was managed in a one-hectare forested paddock at the Tabin Wildlife Reserve, Sabah, Malaysia. In January 2017, it showed signs of difficulty in mastication, especially chewing on larger stems. Subsequently, in February 2017, it developed a $5 \mathrm{~cm}$ left unilateral, infraorbital and maxillary swelling with epiphora. It was treated with oral flunixin meglumine (Banamine ${ }^{\circledR}$ at $1500 \mathrm{mg}$ per day for 3 days, and oral amoxicillin and clavulanate potassium (Augmentin ${ }^{\mathrm{TM}}$ ) for five consecutive days. However, within a month, the swelling rapidly developed into a firm mass measuring about $15 \mathrm{~cm}$ in diameter, which later ruptured to discharge a mucopurulent exudate. In addition to wound cleaning twice a day, the rhinoceros was treated with oral amoxicillin and clavulanate potassium (Augmentin ${ }^{\mathrm{TM}}$ ) at $25 \mathrm{mg} / \mathrm{kg}$ for 5 days, and parenteral dexamethasone (Dexadreson ${ }^{\circledR}$ ) at $0.1 \mathrm{mg} / \mathrm{kg}$ intramuscularly for 3 days. Despite the treatment, the wound did not show any improvement and eventually became a $5 \mathrm{~cm}$ over-granulated open wound with blood-tinged nasal discharge from the left nostril. At this point, the appetite and body weight were slightly reduced, while the right jaw was predominantly used for mastication.

Staphylococcus sp. was isolated from the swab sample of the open wound, while an antibiotic sensitivity test showed resistance to amoxicillin-clavulanate acid but susceptibility to enrofloxacin and cephalosporin. In April 2017, a radiograph revealed a unilocular radiolucent area surrounding the 2 nd and 3rd maxillary cheek teeth, suggestive of a cyst (Figure 1A). This cyst was connected to the paranasal sinuses by an oronasal fistula. A radiopaque fragment was noted dorsal to the 3rd maxillary cheek tooth, indicating a fracture of alveolar bone. The rhinoceros was orally treated with dexamethasone, Augmentin ${ }^{\mathrm{TM}}$, lactated Ringer's solution, dextrose, Duphalyte, vitamin K, iron supplement, and phenylbutazone.

Dental extraction surgery was performed with peri-operative treatment comprising flunixin meglumine and enrofloxacin. Three cheek teeth (1st, 2nd, and 3rd cheek teeth) were successfully extracted in the surgery. All the extracted teeth had yellowish expansile solid masses around the roots. However, the oronasal fistula was not examined, as it could not be reached through the alveolar opening. For post-operative treatment, phenylbutazone, enrofloxacin, ceftiofur, and oral rinse were administered.

Thirty minutes after the recovery from anesthesia, the animal regained normal appetite. Wound cleaning, mouth wash, and parenteral enrofloxacin once daily, every other day were continued. However, the open wound, nasal discharge, and epiphora persisted. Thus, the antibiotic was changed to ceftiofur on day 8 after dental extraction. The bodyweight increased to $512 \mathrm{~kg} 7$ days after the surgery. The intraoral granulation tissue eventually subsided. However, between May and June 2017, the animal showed occasional epistaxis and dyspnea, while the cutaneous mass aggressively grew larger. The rhinoceros was euthanized by intravenous administration of detomidine, ketamine, and pentobarbitone. 

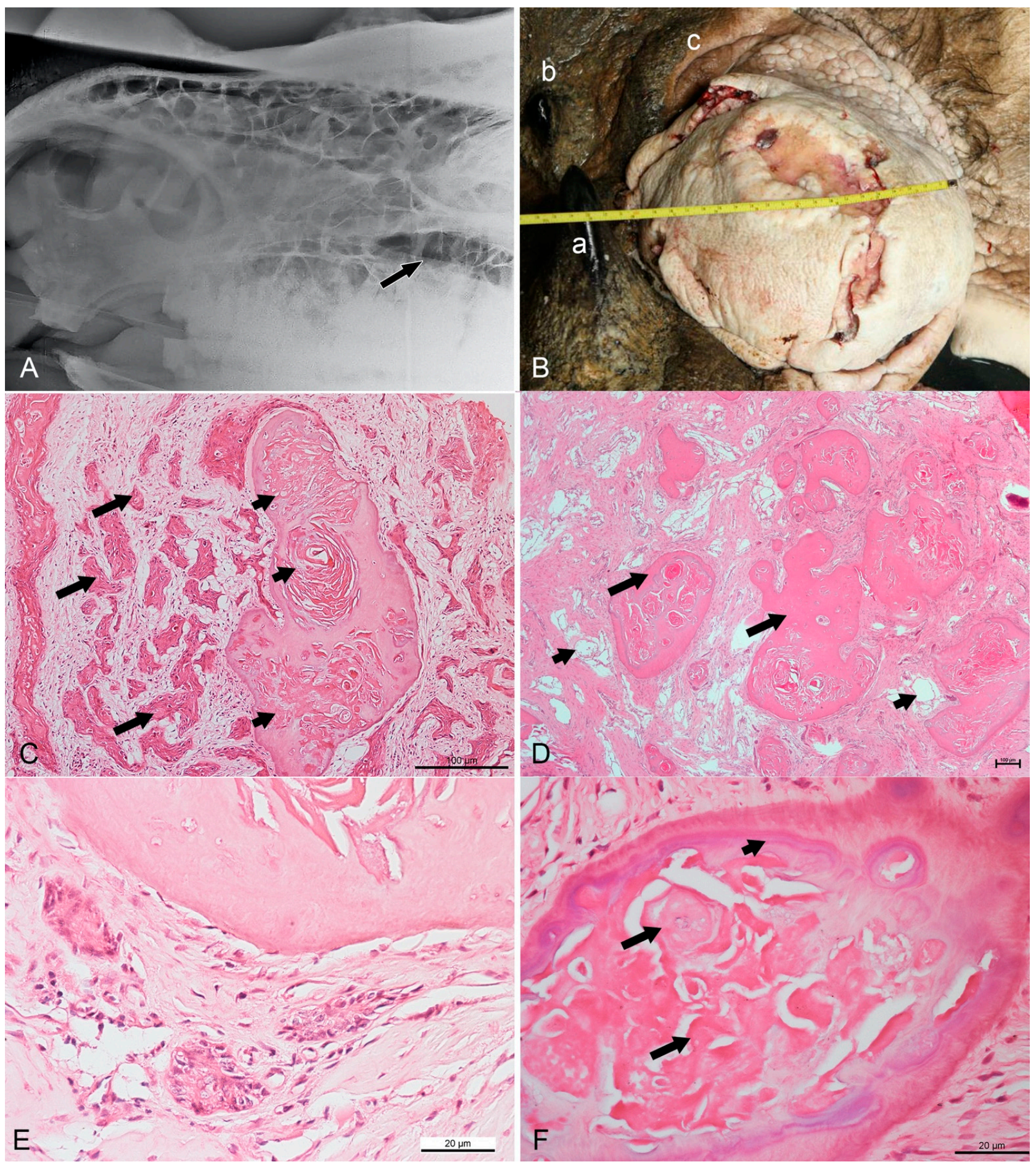

Figure 1. Radiographic, gross, and routine histopathological findings in a Sumatran rhinoceros with a dentinogenic ghost cell tumor. (A) Left-lateral view radiograph taken in April 2017 showing a unilocular radiolucent cyst (arrow) at the left maxilla. (B) The infraorbital mass in June 2017 measuring $21 \mathrm{~cm} \times 30 \mathrm{~cm}$. a: anterior horn, b: posterior horn, c: left upper eyelid. (C) Nests of neoplastic squamous cells (long arrows) surrounded by substantial compact fibrous stroma. Note the formation of keratin pearls (short arrows) embedded in a dentinoid material. HE (hematoxylin and eosin), bar $=100 \mu \mathrm{m}$. (D) Numerous islands of dentinoid material (long arrows) surrounded by loose and vascularized stroma (short arrows). HE, bar $=100 \mu \mathrm{m}$. (E) Neoplastic cells showing pleomorphism with basaloid- or stellate-reticulum-like appearance arranged in a nest. Vesicular nuclei can be observed. HE, bar $=20 \mu \mathrm{m}$ (F) Ghost cell (long arrows) at the center of dentinoid material with cementum-like appearance (short arrow). HE, bar $=20 \mu \mathrm{m}$. 
During the post-mortem examination, a tissue mass was visible around the dental extraction site, with the remaining 2 nd and 3rd molars having enormous amounts of the expansile solid mass around the crowns and roots. The skin around the open wound was edematous and swollen. The infraorbital mass measured $21 \times 30 \mathrm{~cm}$ (Figure 1B), with several open wounds of 1 to $7 \mathrm{~cm}$ in diameter. The mass extended ventrally and dorsal into the eyes. The size and color of the left masseter muscles were darker compared to the opposite side, suggestive of degenerative changes. Fistula between the maxilla and infraorbital mass was noted, while the left parotid gland was gritty with whitish spots. No metastasis to either adjacent or distant organs was observed. Samples from the infraorbital mass, left parotid gland, and left masseter muscle were collected and fixed in 10\% neutral-buffered formalin, routinely processed, and stained with hematoxylin and eosin (HE), special histochemical Masson's trichrome and Von Kossa stains, and immunohistochemistry was conducted for detection of cytokeratin AE1/AE3, epithelial membrane antigen (EMA), p53, and S-100.

In the infraorbital mass, islands of neoplastic epithelium of various sizes were observed embedded or infiltrated in substantial amounts of either compact or loose fibrous stroma (Figure 1C). In some areas, the stroma was extensively loose with increased vascularization (Figure 1D). The neoplastic cells showed an infiltrative growth pattern arranged in strands, unsuccessful anastomosing, or medusa-like patterns. A long trabecular arrangement of tumor cells was observed. Multifocal squamous metaplasia or keratin-like material deposition was noted in the centers of the tumor islands. The tumor cells could be seen surrounding and embedded in numerous islands of dentinoid material. In addition, accumulation of pale eosinophilic ghost cells and a whirl-like arrangement of keratin-like material infiltrating the dentinoid material were noticeable. At high magnification, the neoplastic cells showed pleomorphism with a basaloid- or stellate-reticulum-like appearance with vesicular nuclei, usually arranged in a nest (Figure 1E). Ghost cells, characterized by large, eosinophilic cells that contained either the outline of a nucleus or no nucleus, were present at the cementum-like appearance of the dentinoid materials (Figure 1F). Mitoses were occasionally seen. The mitotic count, determined using a previously described method, was a low count of 2 [10]. The dentinoid was further confirmed by positive staining using Von Kossa stain to indicate the presence of calcium, and blue staining by Masson's trichrome stain. Most of the keratin and ghost cells lacked calcium, as indicated by the negative staining by Von Kossa stain (Figure 2A) and red staining by Masson's trichrome stain (Figure 2B). Some keratin pearls were observed without dentinoid formation, but they were surrounded by substantial amounts of neoplastic epithelial cells. The left masseter muscle was mildly degenerated but showed no evidence of invasion by neoplastic cells, while the left parotid gland was severely calcified.

The neoplastic epithelial cells showed intense intracytoplasmic immunodetection of cytokeratin AE1/AE3 but were negative for EMA and S-100. All keratin pearls, including those found inside the dentinoid material, and most of the ghost cells, showed intense staining with cytokeratin AE1 / AE3 (Figure 2C), mild staining against S-100 (Figure 2D), and negative against p53 and EMA.

The differential diagnoses for this case included ghost cell odontogenic carcinoma (GCOC), dentinogenic ghost cell tumor (DGCT), craniopharyngioma, primary intraosseous squamous cell carcinoma (PIOSCC), squamous cell carcinoma (SCC), and ameloblastoma. The radiology and histopathology examinations established the diagnosis of DGCT. 


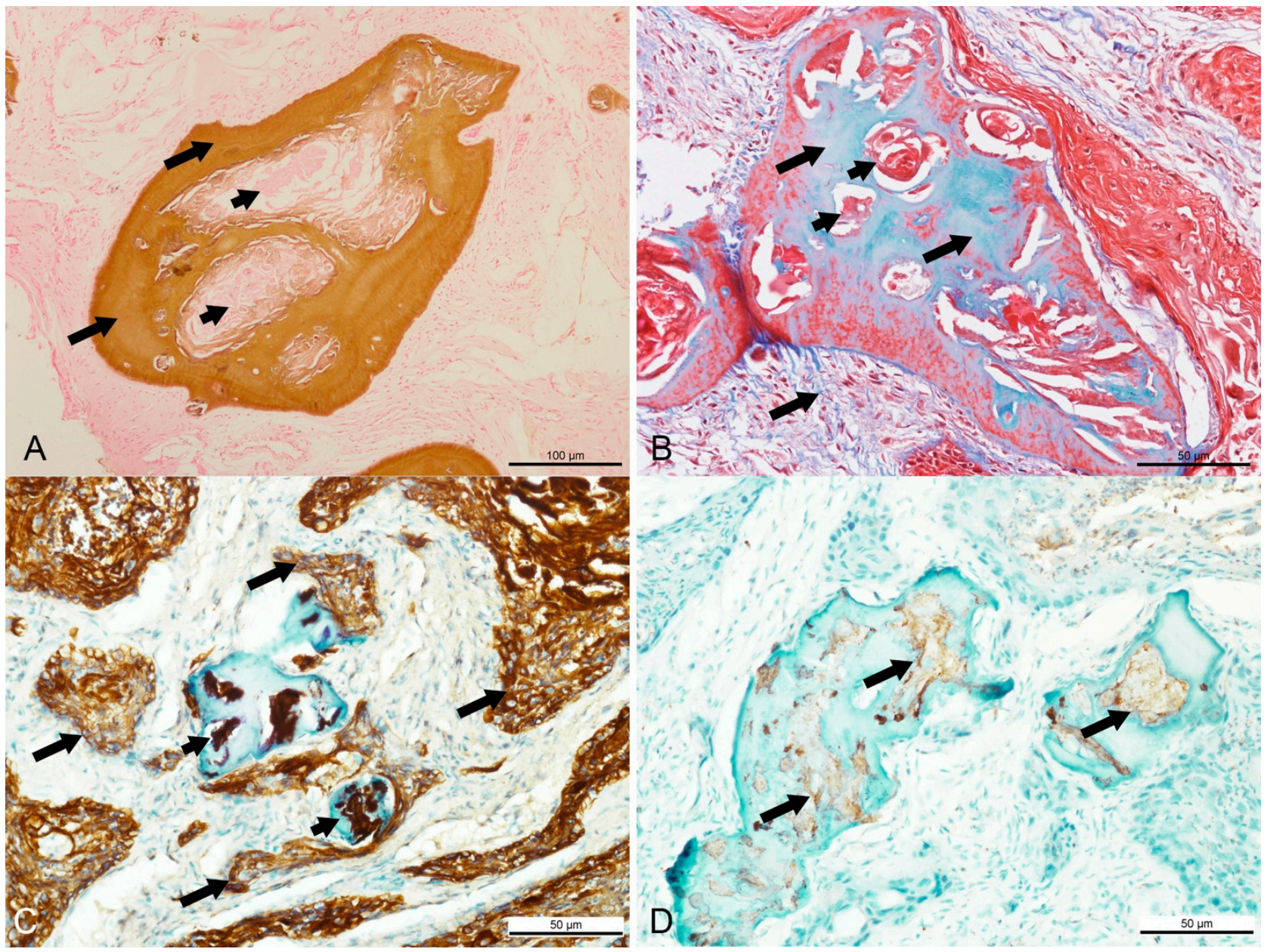

Figure 2. Special histochemical and immunohistochemistry findings in a Sumatran rhinoceros with a dentinogenic ghost cell tumor. (A) Brown stain of Von Kossa indicating the presence of calcium in the dentinoid material (long arrow), while most keratin pearls were devoid of calcium (short arrows). Von Kossa, bar $=100 \mu \mathrm{m}$. (B) Bone tissue stained in blue and keratin stained in red with Masson's trichrome. Masson's trichrome, bar $=50 \mu \mathrm{m}$. (C) Intense intracytoplasmic staining for cytokeratin AE1/AE3 in the neoplastic squamous cells (long arrows) and keratin pearls (short arrows). AE1/AE3, bar $=50 \mu \mathrm{m}$. (D) Mild positive staining for S-100 in the ghost cells and keratin (arrows) located inside the dentinoid material. S-100, bar $=50 \mu \mathrm{m}$.

\section{Discussion}

OGCL are considered challenging to diagnose, as COC, DGCT, and GCOC have similar histological features [11]. Diagnosis of DGCT in this rhinoceros was largely made based on the histological and immunohistochemical features from human oncology and pathology as compiled in Table 1. From the differential diagnoses, PIOSCC, SCC and ameloblastoma were ruled out, as these tumors do not feature ghost cell lesions [12]. GCOC was ruled out mainly by the fact that histopathological examination showed low mitotic activity, suggestive of a benign cellular status. Furthermore, it did not invade adjacent tissues, lacked necrosis, had pleomorphic neoplastic cells, and the immunohistochemistry for p53 was negative. Although about $30 \%$ of GCOC may show negativity for p53, it has been reported that the diagnosis of GCOC versus DGCT should be largely based on p53 positivity $[3,13]$. Formation of dentinoid material in craniopharyngioma is extremely rare. If present, these dentinoid materials are described as not obvious [14], so craniopharyngioma was ruled out. From this case and bibliographical review, it was stated that differentiating DGCT, GCOC, and other differential diagnoses based on the epithelial histological and immunochemical features can be difficult. The reason for this is that they may show similar epithelial features ranging from palisading columnar (resembling ameloblastoma) 
to basaloid (resembling squamous epithelium) formations. The presence of foreign body giant cells has been reported in both DGCT and GCOC $[15,16]$. Because of the rarity of OGCL and the many synonyms for each OGCL neoplasm, available data pertaining to their immunohistochemical characteristics may be difficult to access.

Table 1. Summary of histological and immunohistochemical features of COC, DGCT, and GCOC in humans.

\begin{tabular}{|c|c|c|c|c|}
\hline & $\mathrm{COC}$ & DGCT & GCOC & References \\
\hline \multicolumn{5}{|c|}{ Histological Features } \\
\hline Cyst component & Main & Occasional & Occasional & [17] \\
\hline Epithelium & $\begin{array}{l}\text { Mainly cystic } \\
\text { Palisading columnar cells } \\
\text { resembling ameloblastoma }\end{array}$ & $\begin{array}{c}\text { Tumorous and } \\
\text { occasionally cystic } \\
\text { Ameloblastous or basaloid }\end{array}$ & $\begin{array}{l}\text { Tumorous and rarely cystic } \\
\text { Uniform small basaloid, } \\
\text { with round or } \\
\text { vesicular nuclei }\end{array}$ & {$[3,17]$} \\
\hline Ghost Cell & Consistent & Marked & Predominant & [17] \\
\hline Calcification & Frequent & Occasional & Rare & [17] \\
\hline Dentinoid Material & None & Predominant & Rudimentary & [17] \\
\hline Cellular status & Benign & Benign & Malignant & [17] \\
\hline Mitosis & Present & Rare & Frequent & {$[3]$} \\
\hline Recurrence & Rare & Rare & Frequent & [17] \\
\hline \multicolumn{5}{|c|}{ Immunohistochemistry Features } \\
\hline $\begin{array}{l}\text { Cytokeratin } \\
\text { AE1/AE3 }\end{array}$ & + & + & + & {$[18,19]$} \\
\hline Beta catenin & + & + & + & {$[20,21]$} \\
\hline S-100 & $+/-$ & + & $+1-$ & {$[18,22-24]$} \\
\hline EMA & $\mathrm{n} / \mathrm{a}$ & $\mathrm{n} / \mathrm{a}$ & - & [18] \\
\hline p53 & $\mathrm{n} / \mathrm{a}$ & $+/-$ & $\begin{array}{c}+/- \\
(>70 \% \text { of cases show }+)\end{array}$ & {$[3,18,19,25]$} \\
\hline
\end{tabular}

In general, DGCT more commonly occurs in the posterior maxilla and mandible. A slight predilection for the mandible has been reported, where $53 \%$ of DGCT occurs in the mandible [3]. Two variants of DGCT, namely, central and peripheral, have been described [26]. Central DGCT, the more common of the two, is a locally invasive intraosseous tumor, whereas peripheral DGCT is a non-invasive extraosseous tumor [27]. In most cases of central DGCT, the radiographic features are unilocular with a mixture of radiolucent and radiopaque or only radiolucent lesions [3]. It is unfortunate that no sample from the maxillary cyst was collected and examined in this case. The radiographic observation of mandibular cyst in this rhinoceros suggested that this case involved a central DGCT.

Cases of other OGCL in animals have been previously reported, such as epithelial ghost cells and dentinoid material in rats with odontogenic tumors [28]. Another report involved a Bengal tiger (Panthera tigris tigris), wherein only a few ghost cells and some keratin were observed in a mandibular mass. However, no formation of dentinoid material was observed. That case was diagnosed as calcifying epithelial odontogenic tumor [29]. It is possible that the lack of reports of GCOC is due to the rarity of the tumor or the general lack of classification of odontogenic tumors in veterinary medicine [30]. Histological similarities were observed with the previously reported odontogenic tumors in rats, wherein no ameloblastoma-like tumor cells were seen and ovoid neoplastic epithelial cells predominated [28]. But this was very different from DGCT in humans, wherein ameloblastomatous proliferation is typically obvious [3,17].

In megavertebrates, oral and facial proliferative lesions have been previously reported. This includes cases of gingivitis, tooth root abscessation, and SCC [31-33]. It is important 
to conduct routine clinical examinations and detailed histopathological examinations to properly diagnose these lesions. Despite its rarity, OGCL should be considered in cases of oral and facial proliferative lesions in megavertebrates and animals in general.

\section{Conclusions}

This is the first report of DGCT in veterinary medicine. The diagnosis of DGCT in this case was made based on routine histopathology, special histochemistry, and immunohistochemistry with human oncology and pathology as a reference. The histopathology and immunohistochemistry of DGCT in this rhinoceros match the majority of descriptions of DGCT in humans.

Author Contributions: Conceptualization, A.S. and M.Z.-S.; investigation, A.S., C.-R.J.; resources, A.S., Z.Z.Z.; data curation, Z.Z.Z., R.M.M.T., C.K.Y.; writing-original draft preparation, A.S.; writing - review and editing, M.Z-S., Z.Z.Z., C.-R.J. All authors have read and agreed to the published version of the manuscript.

Funding: This research was funded by the Federal Government of Malaysia, State Government of Sabah, and Sime Darby Foundation, and the APC was funded by Universiti Putra Malaysia.

Institutional Review Board Statement: Ethical review and approval were waived for this study because the study was non-experimental, and the samples analyzed were either part of clinical management or obtained in a necropsy.

Data Availability Statement: Not applicable.

Acknowledgments: The authors thank the staff of Borneo Rhino Alliance, especially the rhinoceros' keepers and field staff for attending to the rhinoceros at the Tabin Wildlife Reserve, as well as John Payne and Abdul Hamid Ahmad for their technical support. We also thank the veterinarians at the Sabah Wildlife Department for their assistances.

Conflicts of Interest: The authors declare no conflict of interest.

\section{References}

1. $\quad$ de Arruda, J.A.A.; Monteiro, J.L.G.C.; Abreu, L.G.; de Oliveira Silava, L.G.; Schuch, L.F.; de Noronha, M.S.; Callou, G.; Moreno, A.; Mesquita, R.A. Calcifying odontogenic cyst, dentinogenic ghost cell tumor, and ghost cell odontogenic carcinoma: A systematic review. J. Oral Pathol. Med. 2018, 47, 721-730. [CrossRef]

2. Flucke, U. Malignant Neoplasms of the Gnathic Bones. In Head and Neck Pathology, 3rd ed.; Thompson, L.D.R., Bishop, J.A., Eds.; Elsevier: Philadelphia, PA, USA, 2019; pp. 417-432.

3. Takata, T.; Slooweg, P.J. WHO classification of odontogenic and maxillofacial bone tumours. In WHO Classification of Head and Neck Tumour, 4th ed.; El-Naggar, A.K., Chan, J.K.C., Grandis, J.R., Takata, T., Slootweg, P.J., Eds.; International Agency for Research on Cancer: Lyon, France, 2017; pp. 204-260.

4. Bilodeau, E.A.; Seethala, R.R. Update on odontogenic tumors: Proceedings of the North American Head and Neck Pathology Society. Head Neck Pathol. 2019, 13, 457-465. [CrossRef]

5. Daniels, J.S.M. Recurrent calcifying odontogenic cyst involving the maxillary sinus. Oral Surg. Oral Med. Oral Pathol. Oral Radiol. Endod. 2004, 98, 660-664. [CrossRef] [PubMed]

6. Wright, B.A.; Bhardwaj, A.K.; Murphy, D. Recurrent calcifying odontogenic cyst. Oral Surg. Oral Med. Oral Pathol. Oral Radiol. Endod. 1984, 58, 579-583. [CrossRef]

7. Buchner, A.; Akrish, S.J.; Vered, M. Central dentinogenic ghost cell tumor: An update on a rare aggressive odontogenic tumor. J. Oral Maxillofac. Surg. 2016, 74, 307-314. [CrossRef]

8. Juneja, M.; George, J. Dentinogenic ghost cell tumor: A case report and review of the literature. Oral Surg. Oral Med. Oral Pathol. Oral Radiol. Endod. 2009, 107, e17-e22. [CrossRef] [PubMed]

9. Martos-Fernández, M.; Alberola-Ferranti, M.; Hueto-Madrid, J.A.; Bescós-Atín, C. Ghost cell odontogenic carcinoma: A rare case report and review of literature. J. Clin. Exp. Dent. 2014, 6, e602. [CrossRef]

10. Meuten, D.J.; Moore, F.M.; George, J.W. Mitotic count and the field of view area: Time to standardize. Vet. Pathol. 2016, 53, 7-9. [CrossRef] [PubMed]

11. Regezi, J.A. Odontogenic cysts, odontogenic tumors, fibroosseous, and giant cell lesions of the jaws. Mod. Pathol. 2002, 15, 331-341. [CrossRef]

12. Comolli, J.R.; Olsen, H.M.; Seguel, M.; Schnellbacher, R.W.; Fox, A.J;; Divers, S.J; Sakamoto, K. Ameloblastoma in a wild black rat snake (Pantherophis alleghaniensis). J. Vet. Diagn. Investig. 2015, 7, 536-539. [CrossRef]

13. Del Corso, G.; Tardio, M.L.; Gissi, D.B.; Marchetti, C.; Montebugnoli, L.; Tarsitano, A. Ki-67 and p53 expression in ghost cell odontogenic carcinoma: A case report and literature review. Oral Maxillofac. Surg. 2015, 19, 85-89. [CrossRef] [PubMed] 
14. Badger, K.V.; Gardner, D.G. The relationship of adamantinomatous craniopharyngioma to ghost cell ameloblastoma of the jaws: A histopathologic and immunohistochemical study. J. Oral Maxillofac. Pathol. 1997, 26, 349-355. [CrossRef] [PubMed]

15. Singhaniya, S.B.; Barpande, S.R.; Bhavthankar, J.D. Dentinogenic ghost cell tumor. J. Oral Maxillofac. Pathol. $2009,13,97$. [CrossRef]

16. Ali, E.A.M.; Karrar, M.A.; El-Siddig, A.A.; Gafer, N.; Satir, A.A. Ghost cell odontogenic carcinoma of the maxilla: A case report with a literature review. Pan Afr. Med. J. 2015, 21. [CrossRef]

17. Lee, S.K.; Kim, Y.S. Current concepts and occurrence of epithelial odontogenic tumors: II. Calcifying epithelial odontogenic tumor versus ghost cell odontogenic tumors derived from calcifying odontogenic cyst. Korean J. Pathol. 2014, 48, 175. [CrossRef]

18. Folpe, A.L.; Tsue, T.; Rogersoin, L.; Weymuller, E.; Ods, D.; True, L.D. Odontogenic ghost cell carcinoma: A case report with immunohistochemical and ultrastructural characterization. J. Oral Pathol. Med. 1998, 27, 185-189. [CrossRef]

19. Piattelli, A.; Fioroni, M.; Di Alberti, L.; Rubini, C. Immunohistochemical analysis of a dentinogenic ghost cell tumour. Oral Oncol. 1998, 34, 502-507. [CrossRef]

20. Sekine, S.; Sato, S.; Takata, T.; Fukuda, Y.; Ishida, T.; Kishino, M.; Shibata, T.; Kanai, Y.; Hirohashi, S. $\beta$-catenin mutations are frequent in calcifying odontogenic cysts, but rare in ameloblastomas. Am. J. Pathol. 2003, 163, 1707-1712. [CrossRef]

21. Rappaport, M.J.; Showell, D.L.; Edenfield, W.J. Metastatic ghost cell odontogenic carcinoma: Description of a case and search for actionable targets. Rare Tumors 2015, 7, 96-97. [CrossRef] [PubMed]

22. Pinheiro, T.N.; de Souza, A.P.F.; Bacchi, C.E.; Consolaro, A. Dentinogenic ghost cell tumor: A bibliometric review of literature. J. Oral Dis. Mark. 2019, 3, 9-17. [CrossRef]

23. Kasai, T.; Kamegai, A.; Kubota, K.; Sato, K.; Kanematsu, N.; Mori, M. S-100 Protein Immunoreactivity of Calcifying/calcified Areas in Odontogenic Tumors. Oral Med. Pathol. 2002, 7, 19-25. [CrossRef]

24. Richardson, M.S.; Muller, S. Malignant odontogenic tumors: An update on selected tumors. Head Neck Pathol. 2014, 8, 411-420. [CrossRef]

25. Iezzi, G.; Rubini, C.; Fioroni, M.; Piattelli, A. Peripheral dentinogenic ghost cell tumor of the gingiva. J. Periodontol. 2007, 78, 1635-1638. [CrossRef] [PubMed]

26. Candido, G.A.; Viana, K.A.; Watanabe, S.; Vencio, E.F. Peripheral dentinogenic ghost cell tumor: A case report and review of the literature. Oral Surg. Oral Med. Oral Pathol. Oral Radiol. Endod. 2009, 108, e86-e90. [CrossRef]

27. Jayasooriya, P.R.; Mendis, B.R.R.N.; Lombardi, T. A Peripheral Dentinogenic Ghost Cell Tumor With Immunohistochemical Investigations and a Literature Review-Based Clinicopathological Comparison Between Peripheral and Central Variants. Int. J. Surg. Pathol. 2015, 23, 489-494. [CrossRef] [PubMed]

28. Cullen, J.M.; Ruebner, B.H.; Hsieh, D.P.H.; Burkers, E.J., Jr. Odontogenic tumors in Fischer rats. J. Oral Pathol. Med. 1987, 16, 469-473. [CrossRef]

29. Kang, M.S.; Park, M.S.; Kwon, S.W.; Ma, S.A.; Cho, D.Y.; Kim, D.Y.; Kim, Y. Amyloid-producing odontogenic tumour (calcifying epithelial odontogenic tumour) in the mandible of a Bengal tiger (Panthera tigris tigris). J. Comp. Pathol. 2006, 134, 236-240. [CrossRef] [PubMed]

30. Murphy, B.G.; Bell, C.M.; Soukup, J.W. Odontogenic Tumors. In Veterinary Oral and Maxillofacial Pathology; Wiley Blackwell: Hoboken, NJ, USA, 2020; pp. 91-128.

31. de Oliveira, A.R.; Arenales, A.; de Carvalho, T.P.; Pessanha, A.T.; Tinoco, H.P.; da Costa, M.E.L.T.; da Paixao, T.A.; Santos, R.L. Metastatic oral squamous cell carcinoma in a captive common hippopotamus (Hippopotamus amphibius). Braz. J. Vet. Pathol. 2018, 11, 64-67. [CrossRef]

32. Dennis, P.M.; Funk, J.A.; Rajala-Schultz, P.J.; Blumer, E.S.; Miller, R.E.; Wittum, T.E.; Saville, W.J. A review of some of the health issues of captive black rhinoceroses (Diceros bicornis). J. Zoo Wildl. Med. 2007, 38, 509-517. [CrossRef] [PubMed]

33. Langer, S.; Czerwonka, N.; Termes, K.; Herbst, W.; Koehler, K. Oral squamous cell carcinoma in an aged captive white rhinoceros (Ceratotherium simum). J. Zoo Wildl. Med. 2016, 47, 1090-1092. [CrossRef] 